\title{
Penggunaan Model Pembelajaran Direct Instruction Sebagai Upaya Meningkatkan Prestasi Belajar IPS
}

\author{
Ni Nyoman Sekar ${ }^{1 *}$ iD \\ ${ }^{I}$ SD Negeri 6 Gianyar, Gianyar, Indonesia \\ *Corresponding author: ninnymnsekar44@gmail.com
}

\begin{abstract}
Penelitian ini dilaksanakan di SD yang prestasi belajarnya masih rendah. Tujuan penulisan penelitian tindakan kelas ini adalah untuk mengetahui apakah model Direct Instruction dapat meningkatkan prestasi belajar siswa. subjek penelitian tindakan ini adalah kelas IV SD. Metode pengumpulan datanya adalah tes prestasi belajar. Metode analisis datanya adalah deskriptif. Hasil yang diperoleh dari penelitian ini adalah model Direct Instruction dapat meningkatkan prestasi belajar siswa. Ini terbukti dari hasil yang diperoleh pada pada awalnya 68,24 setelah diberikan tindakan pada siklus I meningkat menjadi 69,86 dan pada siklus II meningkat lagi menjadi 80,13. Kesimpulan yang diperoleh dari penelitian ini adalah model Direct Instruction dapat meningkatkan prestasi belajar IPS siswa kelas IV A SD.
\end{abstract}

Keywords: Direct Instruction, Prestasi Belajar IPS

\section{Abstract}

This research was conducted in elementary schools with low learning achievement. The purpose of writing this classroom action research is to determine whether or not the Direct Instruction model can improve student achievement. The subject of this action research is grade IV of elementary school. The data collection method is a learning achievement test. And the data analysis method is descriptive. The results obtained from this study show that the Direct Instruction model can improve student achievement. This is proved that the results obtained at the beginning was 68.24 and after given action in cycle I increased to 69.86 then in cycle II increased to 80.13. It is concluded that the Direct Instruction model can improve the social studies learning achievement of grade IV A elementary school students.

Keywords: Direct Instruction, Social Studies Learning Achievement

\section{Introduction}

Dalam proses pembelajaran yang berlangsung di kelas, untuk dapat mencapai tujuan yang maksimal seperti yang diharapkan harus terjadi komunikasi aktif antara guru selaku penyampai informasi dengan siswa sebagai penerima informasi atau pengetahuan. Komunikasi yang akan dijalin oleh guru selaku agen dalam pembelajaran harus dimulai dengan perencanaan yang baik, sehingga alur pembelajaran yang dilakukan dapat berjalan secara sistematis dan terarah. Seperti yang dinyatakan Fakhrurrazi, (2018) dan Uno, (2010) bahwa istilah pembelajaran memiliki hakikat perencanaan atau perancangan (desain) sebagai upaya untuk membelajarkan siswa. Itulah sebabnya siswa-siswa tidak hanya berinteraksi dengan guru sebagai salah satu sumber belajar, tetapi mungkin berinteraksi dengan keseluruhan sumber belajar yang dipakai untuk mencapai tujuan pembelajaran yang

$\begin{array}{lll}\text { History: } & \text { Publisher: Undiksha Press } \\ \text { Received } & : 11 \text { Mei } 2020 & \text { Licensed: This work is licensed under } \\ \text { Revised } & : 29 \text { Mei } 2020 & \text { a Creative Commons Attribution 3.0 License } \\ \text { Accepted : } 26 \text { Juni } 2020 & \text { CC OP OP } \\ \text { Published : } 30 \text { Juli } 2020 & \end{array}$


diinginkan. Oleh karena itu, pembelajaran yang terjadi memusatkan perhatian pada bagaimana membelajarkan siswa dan bukan pada apa yang dipelajari siswa.

Untuk dapat membelajarkan siswa sesuai apa yang diharapkan, guru harus didukung dengan pengetahuan dan pemahaman standar yang mesti dikuasai sesuai metodik dan didaktik, agar dapat mengelola secara profesional mata pelajaran yang diampunya. Kompetensi pedagogi yang dimaksud menurut Mulyasa (2016) sekurang-kurangnya meliputi: (a) pemahaman wawasan atau landasan kependidikan; (b) pemahaman terhadap peserta didik; (c) pengembangan kurikulum/silabus; (d) perancangan pembelajaran; (e) pelaksanaan pembelajaran yang mendidik dan dialogis; (f) pemanfaatan teknologi pembelajaran; (g) evaluasi hasil belajar; dan (h) pengembangan peserta didik untuk mengaktualisasikan berbagai potensi yang dimilikinya.

Harapan nyata yang diinginkan di lapangan terkadang tidak selalu sejalan. Banyak faktor yang menjadi penyebab tidak terwujudnya harapan tersebut, seperti: kurangnya kemauan guru mengembangkan model pembelajaran, kemampuan guru memahami inti pembelajaran, kemampuan guru melaksanakan teori-teori pembelajaran terbaru, kemampuan guru memahami karakteristik peserta didik, kelengkapan sarana prasarana yang ada di sekolah, kemampuan anak mengikuti proses pembelajaran, dan lain-lain. Faktor-faktor yang disebutkan tersebut sangat berpengaruh terhadap pencapaian hasil tes yang diberikan pada siswa kelas IV A semester I tahun pelajaran 2018/2019 di SD Negeri 6 Gianyar ternyata baru mencapai nilai rata-rata 68,24 dengan persentase ketuntasan belajar sebesar 51,35\%.

Mengatasi kesenjangan antara harapan dengan kenyataan di lapangan, memotivasi peneliti sebagai guru kelas IV A di SD Negeri 6 Gianyar mengupayakan peningkatan prestasi belajar IPS siswa dengan menerapkan model Direct Instruction. Model pembelajaran langsung dipilih karena dalam pelajaran IPS materinya berupa suatu proses yang berkelanjutan dan sulit dipelajari sendiri oleh siswa sehingga perlu dipelajari secara bertahap (selangkah demi selangkah) dengan bantuan langsung dari guru (Trianto, 2017). Model pembelajaran langsung adalah salah satu pendekatan mengajar yang dirancang khusus untuk menunjang proses belajar siswa yang berkaitan dengan pengetahuan deklaratif dan pengetahuan prosedural yang terstruktur dengan baik yang dapat diajarkan dengan pola kegiatan yang bertahap, selangkah demi selangkah (Muttaqin et al., 2018; Puryadi et al., 2018; Rainis, 2019). Model Direct Instruction bukan hanya sekedar mengajar dengan cara ceramah akan tetapi banyak metode yang bisa digunakan misalnya demonstrasi, tanya jawab, ceramah dan lain sebagainya (Cahyo, 2019; Multasyam et al., 2016; Suprapto, 2017). Dengan adanya model Direct Instruction kemampuan siswa terstruktur karena proses pembelajaran dipandu oleh guru.

Beberapa penelitian yang dilakukan berkaitan dengan model Direct Instruction antara lain penelitian Susiana \& Wening (2015) yang menemukan bahwa adanya pengaruh penerapan model Direct Instruction, hal ini tampak dari hal penelitiannya terdapat pengaruh penerapan model Direct Instruction terhadap pencapaian kompetensi pembuatan desain busana antara kelas eksperimen dan kelas kontrol, yang dibuktikan dengan hasil perhitungan uji $t$ (t-test) dengan $t_{\text {hitung }} 0,000<t_{\text {tabel }}$ 0,05. Zahrina (2019) menyatakan bahwa hasil belajar SBDP pada materi montase dengan menggunakan model Direct Instruction lebih tinggi dibandingkan dengan siswa yang diajarkan dengan yang tidak menggunakan model Direct Instruction yang dibuktikan dengan adanya peningkatan persentase hasil belajar kognitif, hasil belajar afektif dan hasil belajar psiomotorik siswa. Purnamasari \& Hidayat, (2015) menyatakan bahwa adanya pengaruh model Direct Instruction dengan pendekatan contextual terhadap pemahaman konsep. Lastuti et al. (2018) menyatakan bahwa berdasarkan kriteria pengujian hipotesis menunjukkan thitung $>\mathrm{t}_{\text {tabel }}$ sehingga $\mathrm{H}_{0}$ ditolak dan $\mathrm{H}_{\mathrm{a}}$ diterima. Hal ini membuktikan bahwa adanya perbandingan penggunaan model Problem Based Instruction dengan Direct Instruction di kelas XI TKR SMK Negeri 2 Palembang. 
Berdasarkan jabaran tersebut, maka dirumuskan tujuan penelitian yaitu Tujuan penulisan penelitian tindakan kelas ini adalah untuk mengetahui apakah model Direct Instruction dapat meningkatkan prestasi belajar siswa. Jika langkah-langkah pembelajaran Direct Instructions dimulai dengan hal-hal yang mudah untuk dipecahkan yang disesuaikan dengan langkah-langkah pembelajaran Direct Instruction, maka prestasi belajar siswa kelas IV A SD Negeri 6 Gianyar semester I tahun pelajaran 2018/2019 akan dapat ditingkatkan.

\section{Materials and Methods}

Dalam melaksanakan Penelitian Tindakan Kelas, langkah-langkah atau prosedur PTK didasarkan pada model rancangan PTK dari para ahli. Selama ini dikenal berbagai model PTK, namun pada dasarnya terdapat empat tahap yang harus dilalui yaitu (1) perencanan (planning), (2) pelaksanaan (acting), (3) pengamatan (observing), dan (4) refleksi (reflecting). Keempat tahap tersebut merupakan satu siklus dan akan dapat berlanjut kepada siklus kedua, siklus ketiga dan seterusnya sesuai dengan apa yang diinginkan dalam penelitian.

Untuk penelitian ini penulis memilih rancangan penelitian tindakan yang disampaikan Mc. Kerman seperti terlihat pada Gambar 1.

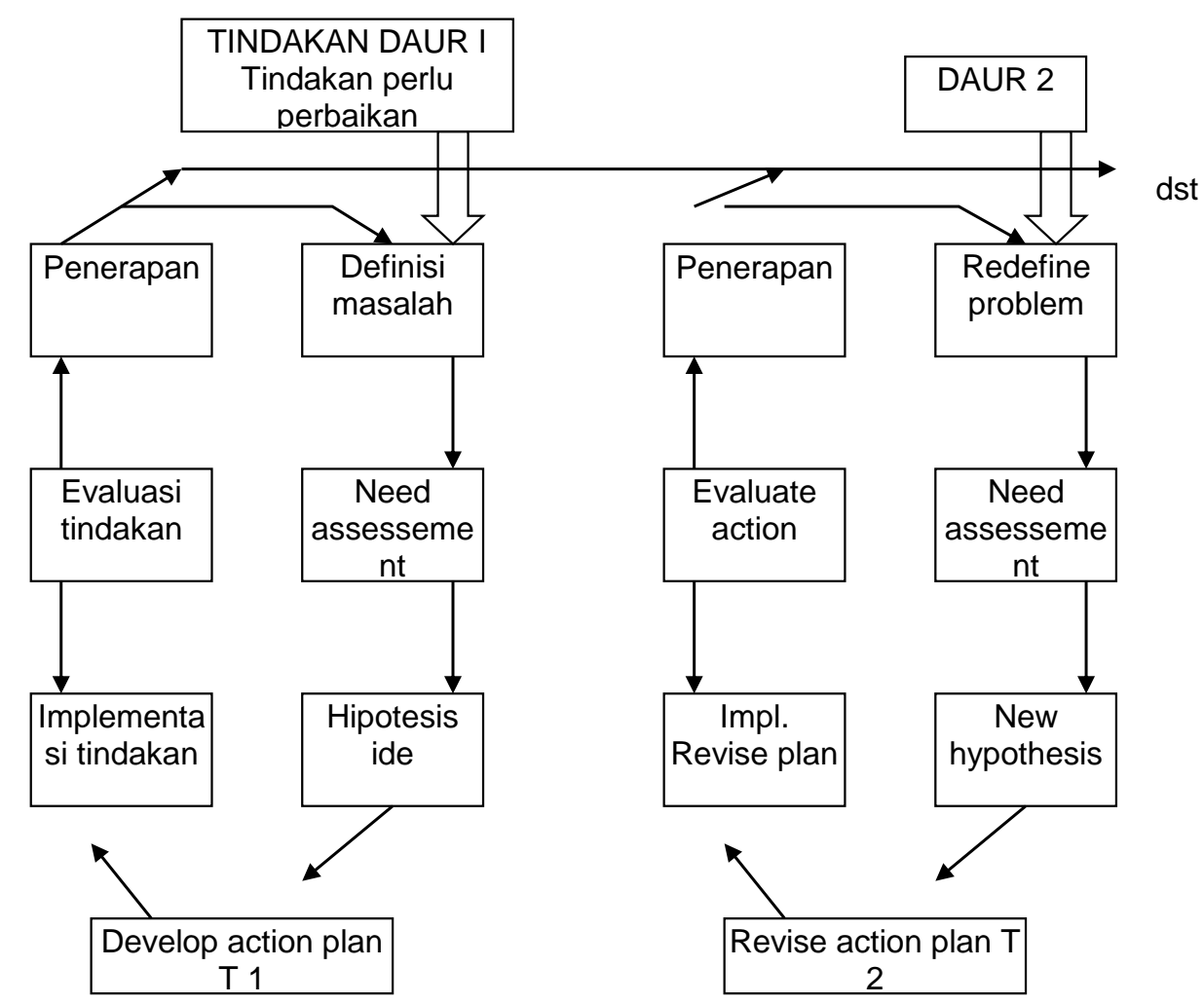

Gambar 1. Penelitian Tindakan Model Mc. Kernan, 1991 (dalam Sukidin, Basrowi, Suranto, 2002: 54)

Tindakan daur I dilakukan definisi masalah dilanjutkan dengan pelaksanaan di lapangan, dirumuskan hipotesisnya, dikembangkan hipotesis tersebut, diimplementasikan, dievaluasi dari hasil yang didapat dan evaluasi diterapkan. Langkah-langkah pada daur II atau siklus II sama dengan yang di siklus I yaitu dimulai dengan adanya suatu permasalahan yang 
baru, didefinisikan masalahnya, dibuat hipotesisnya direvisi, selanjutnya dilakukan implementasi di lapangan, dievaluasi, kemudian hasil yang didapat merupakan penerapan baru apabila masih ada masalah.

Pengumpulan data dalam penelitian ini menggunakan tes prestasi belajar. Tes prestasi belajar berupa tes soal isian maupun essay. Untuk menganalisis data hasil penelitian ini digunakan metode deskriptif. Untuk data kuantitatif dianalisis dengan mencari mean, median, modus, membuat interval kelas dan melakukan penyajian dalam bentuk tabel dan grafik.

Indikator keberhasilan penelitian yang diusulkan dalam penelitian ini pada siklus I dan II mencapai nilai rata-rata 75,00 dengan ketuntasan belajar 85\%. dengan KKM yang ditetapkan untuk mata pelarajan IPS pada SD Negeri 6 Gianyar adalah 70.

\section{Results and Discussion}

Hasil tes prestasi belajar yang merupakan tes yang memforsir siswa untuk betul-betul dapat memahami apa yang sudah dipelajari. Nilai rata-rata siswa di siklus I sebesar 69,86 menunjukkan bahwa siswa setelah menguasai materi yang diajarkan walaupun belum begitu sempurna. Hasil ini menunjukkan peningkatan kemampuan siswa menguasai mata pelajaran IPS. Apabila dibandingkan dengan nilai awal siswa sesuai data yang sudah disampaikan dalam analisis sebelumnya. Hasil tes prestasi belajar di siklus I telah menemukan efek utama bahwa penggunaan model tertentu akan berpengaruh terhadap prestasi belajar siswa yang dalam hal ini adalah model/metode Direct Instruction. Hal ini sesuai dengan hasil meta analisis metode pembelajaran yang dilakukan oleh Arends (2004) dalam (Widiastini, 2020) bahwa model pengajaran langsung dapat meningkatkan hasil belajar kognitif atau pengetahuan deklaratif (mastery of-structured knowledge) dan meningkatkan suatu keterampilan atau pengetahuan prosedural (skill mastery). Seperti telah diketahui bersama bahwasanya mata pelajaran IPS menitik beratkan pembelajaran pada aspek kognitif, afektif, dan Psychomotor sebagai pedoman perilaku kehidupan sehari-hari siswa (Nilasari, 2013). Kendala yang masih tersisa yang perlu dibahas adalah prestasi belajar yang dicapai pada siklus I ini belum memenuhi harapan sesuai dengan tuntutan KKM mata pelajaran IPS di sekolah ini yaitu 70,00. Oleh karenanya upaya perbaikan lebih lanjut masih perlu diupayakan sehingga perlu dilakukan perencanaan yang lebih matang untuk siklus selanjutnya.

Hasil yang diperoleh dari tes prestasi belajar di siklus II menunjukkan bahwa kemampuan siswa dalam mengikuti pelajaran sudah cukup baik. Ini terbukti dari rata-rata nilai siswa mencapai 80,13. Hasil ini menunjukkan bahwa model Direct Instruction telah berhasil meningkatkan prestasi belajar bidang studi IPS siswa kelas IV A. Hasil penelitian ini membuktikan bahwa model/metode yang diterapkan dalam proses pembelajaran berpengaruh secara signifikan terhadap prestasi belajar siswa. Prestasi yang dicapai siswa membuktikan bahwa guru sudah tepat memilih model/metode dalam melaksanakan proses pembelajaran. Setelah dilakukan tindakan dalam dua siklus dapat dilihat perbandingan nilai rata-rata yang diperoleh, dimana pada awalnya nilai rata-rata siswa hanya 68,24 naik di siklus I menjadi 69,86 dan di siklus II naik menjadi 80,13. Kenaikan ini merupakan upaya maksimal yang peneliti laksanakan untuk meningkatkan prestasi belajar siswa terutama meningkatkan mutu pendidikan di SD Negeri 6 Gianyar.

Salah satu indikator proses pembelajaran yang dilakukan oleh guru tercapai dapat dilihat dari prestasi belajar yang ditunjukkan oleh siswa. Prestasi belajar merupakan hasil yang dicapai siswa setelah mempelajari sesuatu. Berdasarkan hasil penelitian yang sudah dijabarkan tersebut terjadi peningkatan pembelajaran dari siklus I hingga siklus II. Hal ini tidak terluas dari model pembelajaran yang digunakan. Model pembelajaran langsung dipilih karena dalam pelajaran IPS materinya berupa suatu proses yang berkelanjutan dan sulit dipelajari sendiri oleh siswa sehingga perlu dipelajari secara bertahap (selangkah demi selangkah) dengan bantuan langsung dari guru (Trianto, 2017). Model pembelajaran 
langsung adalah salah satu pendekatan mengajar yang dirancang khusus untuk menunjang proses belajar siswa yang berkaitan dengan pengetahuan deklaratif dan pengetahuan prosedural yang terstruktur dengan baik yang dapat diajarkan dengan pola kegiatan yang bertahap, selangkah demi selangkah (Muttaqin et al., 2018; Puryadi et al., 2018; Rainis, 2019).

Model Direct Instruction bukan hanya sekedar mengajar dengan cara ceramah akan tetapi banyak metode yang bisa digunakan misalnya demonstrasi, tanya jawab, ceramah dan lain sebagainya (Cahyo, 2019; Multasyam et al., 2016; Suprapto, 2017). Dengan adanya kombinasi dalam model pembelajaran ini membuat siswa tidak bosan mengikuti pembelajaran. Sumiyati, (2017) menyatakan bahwa Dalam proses belajar mengajar, guru perlu mencari tahu pengetahuan, keterampilan dan sikap yang telah dimiliki oleh siswa sehingga tidak terjadi pengulangan materi atau contoh karena akan menimbulkan kebosanan bagi siswa. sedangkan (Akbar et al., 2015) menyatakan bahwa penggunaan alat bantu pembelajaran yang beragam akan dapat menciptakan variasi belajar sehingga tidak menimbulkan kebosanan terhadap siswa. Kebosanan adalah kondisi emosional seseorang merasa dirinya lelah dan jenuh baik secara mental ataupun secara fisik selama mengikuti pembelajaran (Siti Afifah, 2019). Jadi, dapat dikatakan bahwa dengan berkurangnya kebosanan siswa atau pembelajaran tidak menimbulkan rasa bosan maka siswa akan lebih mudah menerima proses pembelajaran, sehingga ini berdampak terhadap prestasi belajar siswa.

Untuk meningkatkan prestasi belajar IPS siswa pada penelitian ini dilakukan dengan menerapkan model pembelajaran Direct Instruction/model pembelajaran langsung. Model pengajaran langsung memiliki ciri-ciri seperti berikut: (1) Adanya tujuan pembelajaran dan pengaruh model pada siswa termasuk prosedur penilaian hasil belajar. (2) Sintaks atau pola keseluruhan dan alur kegiatan pembelajaran. (3) Sistem pengelolaan dan lingkungan belajar model yang diperlukan agar kegiatan pembelajaran tertentu dapat berlangsung dengan berhasil (Trianto, 2009).

Beberapa penelitian yang dilakukan berkaitan dengan model Direct Instruction antara lain penelitian Susiana \& Wening (2015) yang menyatakan bahwa adanya pengaruh penerapan model DI, hal ini tampak dari hal penelitiannya terdapat pengaruh penerapan model DI terhadap pencapaian kompetensi pembuatan desain busana antara kelas eksperimen dan kelas kontrol, yang dibuktikan dengan hasil perhitungan uji t (t-test) dengan thitung 0,000 $<t_{\text {tabel }}$ 0,05. Zahrina (2019) menyatakan bahwa hasil belajar SBDP pada materi montase dengan menggunakan model Direct Instruction lebih tinggi dibandingkan dengan siswa yang diajarkan dengan yang tidak menggunakan model Direct Instruction yang dibuktikan dengan adanya peningkatan persentase hasil belajar kognitif, hasil belajar afektif dan hasil belajar psiomotorik siswa. Purnamasari \& Hidayat (2015) menyatakan bahwa adanya pengaruh model Direct Instruction dengan pendekatan contextual terhadap pemahaman konsep. Lastuti et al. (2018) menyatakan bahwa Berdasarkan kriteria pengujian hipotesis menunjukkan $t_{\text {hitung }}$ $>t_{\text {tabel }}$ sehingga $\mathrm{H}_{0}$ ditolak dan $\mathrm{H}_{\mathrm{a}}$ diterima. Hal ini membuktikan bahwa adanya perbandingan penggunaan model Problem Based Instruction dengan Direct Instruction di kelas XI TKR SMK Negeri 2 Palembang.

\section{Conclusion}

Berdasarkan pemaparan pada pembahasan hasil penelitian di atas, dapat dirangkum temuan sebagai berikut. a) Dari data awal ada 18 siswa mendapat nilai dibawah KKM dan pada siklus I menurun menjadi 14 siswa dan siklus II hanya 2 siswa mendapat nilai di bawah KKM. b) Nilai rata-rata awal 68,24 naik menjadi 69,86 pada siklus I dan pada siklus II naik menjadi 80,13. c) Dari data awal siswa yang tuntas hanya 19 orang sedangkan pada siklus I menjadi lebih banyak yaitu 23 siswa dan pada siklus II menjadi cukup banyak yaitu 35 siswa. 
Hasil temuan di atas membuktikan bahwa model Direct Instruction dapat meningkatkan prestasi belajar IPS Siswa Kelas IV A SD Negeri 6 Gianyar Semester I Tahun Pelajaran $2018 / 2019$

Saran yang dapat disampaikan dari hasil penelitian ini adalah sebagai berikut. Bagi guru kelas, apabila mau melaksanakan proses pembelajaran penggunaan model/metode yang telah diterapkan ini semestinya menjadi pilihan dari beberapa model/metode yang ada mengingat model/metode ini telah terbukti dapat meningkatkan prestasi belajar siswa. Bagi peneliti lain, walaupun penelitian ini sudah dapat membuktikan efek utama dari model/metode Direct Instruction dalam meningkatkan prestasi belajar, sudah pasti dalam penelitian ini masih ada hal-hal yang belum sempurna dilakukan, oleh karenanya disarankan kepada peneliti lain yang berminat meneliti topik yang sama untuk meneliti bagian-bagian yang tidak sempat diteliti.

\section{References}

Akbar, M., Irhasyuarna, Y., \& Rusmansyah. (2015). Pengembangan Media Pembelajaran Multimedia Interaktif Pada Materi Sistem Koloid. Jurnal Inovasi Pendidikan Sains, 6(1), 65-77.

Cahyo, E. D. (2019). Penggunaan Model Pembelajaran Direct Instruction Untuk Mengingkatkan Hasil Belajar Siswa. Tapis : Jurnal Penelitian Ilmiah, 03(1), 39-59.

Fakhrurrazi, F. (2018). Hakikat Pembelajaran Yang Efektif. At-Tafkir, 11(1), 85. https://doi.org/10.32505/at.v11i1.529

Lastuti, F. F. B., Harlin, H., \& Darlius, D. (2018). Perbandingan Hasil Belajar Model Problem Based Instruction Dengan Direct Instruction Di Smkn 2 Palembang. Jurnal Pendidikan Teknik Mesin. https://core.ac.uk/download/pdf/267824504.pdf.

Multasyam, Yani, A., \& Ma'ruf. (2016). Pengaruh Model Pembelajaran Langsung Terhadap Hasil Belajar Fisika Pada Siswa Kelas X SMA Handayani Sungguminasa Kabupaten Gowa. Jurnal Pendidikan Fisika, 4(3), 298-308. http://journal.unismuh.ac.id/index.php/jpf/article/view/328.

Mulyasa. (2016). Pengembangan Implementasi Kurikulum 2013. PT Remaja Rosdakarya.

Muttaqin, N. H., Yamtinah, S., \& Utomo, S. B. (2018). Penerapan Model Pembelajaran Langsung (Direct Instruction) Disertai Diskusi dan Media Hyperchem untuk Meningkatkan Aktivitas dan Prestasi Belajar pada Materi Ikatan Kimia Kelas X 1 SMA Islam 1 Surakarta Tahun Pelajaran 2016/2017. Jurnal Pendidikan Kimia, 7(1), 62. https://doi.org/10.20961/jpkim.v7i1.24564.

Nilasari, E. P. (2013). Penerapan Model Pembelajaran Kooperatif Tipe Numbered Head Together Untuk Meningkatkan Hasil Belajar IPS Kelas V SDN Sidoarjo. Jurnal Penelitian Pendidikan Guru Sekolah Dasar, 1(2).

Purnamasari, N., \& Hidayat, S. H. (2015). PENGARUH MODEL PEMBELAJARAN LANGSUNG ( DIRECT INSTRUCTION ) DENGAN PENDEKATAN KONTEKSTUAL TERHADAP Keywords : Direct Varians terbesar Varians terkecil Keterangan. Jurnal Ilmiah Pendidikan Fisika "Lensa," 4(2), 51-54.

Puryadi, P., Rahayu, S., \& Sutrio, S. (2018). Pengaruh Model Pembelajaran Direct Instruction Berbantuan Bahan Ajar Berbasis Kontekstual Terhadap Hasil Belajar IPA Terapan Siswa Kelas X SMKN 4 Mataram Tahun Ajaran 2015/2016. Jurnal Pendidikan Fisika Dan Teknologi, 4(1), 23. https://doi.org/10.29303/jpft.v4i1.329.

Rainis. (2019). PENERAPAN MODEL PEMBELAJARAN LANGSUNG UNTUK 
MENINGKATKAN HASIL BELAJAR IPA Rainis. Jurnal PAJAR (Pendidikan Dan Pengajaran), 3(6), 1247-1254. https://doi.org/http://dx.doi.org/10.33578/pjr.v3i6.7898.

Siti Afifah. (2019). Pengaruh Kejenuhan Belajar dan Interaksi Sosial Terhadap Konsentrasi Belajar Siswa dengan Sistem Pesantren Modern di Samarinda. PSIKOBORNEO, 7(4), 965-972.

Sumiyati, E. (2017). Penggunaan Model Pembelajaran Interaktif Berbasis Aktivitas Untuk Meningkatkan Prestasi Belajar Siswa Kelas Vi Pada Pelajaran Pkn Sd Negeri 09 Kabawetan. Jurnal PGSD, 10(2), 66-72. https://doi.org/10.33369/pgsd.10.2.66-72.

Suprapto, E. (2017). Pengaruh Model Pembelajaran Kontekstual, Pembelajaran Langsung Dan Motivasi Berprestasi Terhadap Hasil Belajar Kognitif. Innovation of Vocational Technology Education, 11(1), 23-40. https://doi.org/10.17509/invotec.v11i1.4836.

Susiana, R., \& Wening, S. (2015). Pengaruh Model Direct Instruction Berbantuan Multimedia Terhadap Motivasi Belajar Dan the Effect of Multimedia - Aided Direct Instruction on the Learning Motivation for Achievement in the. Jurnal Pendidikan Vokasi, 3(1), 377-393.

Trianto. (2009). Mendesain Model Pembelajaran Inovatif-Progresif. Kencana Prenada Media Group.

Trianto. (2017). Mendesain Model Pembelajaran Inovatif, Progresif, dan Kontekstual. Kencana.

Uno, H. B. (2010). Teori Motivasi dan Pengukurannya. Bumi Aksara.

Widiastini, L. K. (2020). Penggunaan Model Pembelajaran Direct Instruction Sebagai Upaya Meningkatkan Prestasi Belajar IPS. Jurnal Penelitian Dan Pengembangan Pendidikan, $4,135-141$.

Zahrina, H. A. (2019). Penggunaan Model Direct Instruction terhadap Hasil Belajar SBdP pada Materi Montase di Kelas IV SD Negeri Pamulang Tengah. PEDADIDAKTIKA: Jurnal Ilmiah Pendidikan Guru Sekolah Dasar, 6(1), 211-222. 